\title{
三極管制禦波尾截断法による胸部準高圧撮影について
}

\author{
東邦大学医学部放射線医学教室（主任 黒沢 洋教授） \\ 泉重 光・川上賢次 \\ （論交受村 33 年 3 月31日）
}

\section{SEMI-HIGH VOLTAGE CHEST RADIOGRAPHY BY SHUTTING THE TRIODE-CONTROLLED}

\author{
By SHIGEMITSU IZUMI \\ KENII KAWAKAMI \\ Dept. of Radiography Faculty of \\ Medicine Tôhô University \\ (Director : Prof. Dr. Hiroshi Kurokawa)
}

(Article received : March 31, 1958)

\section{Summary}

The semi-high voltage radiography at charged voltage $90 \mathrm{kV}$ and at dischaged voltage $87-89 \mathrm{kV}$ by the condenser dischaged type X-ray apparatus in which a triode-controlled shutting method was applied, was compared with the high voltage radiography at $120 \mathrm{kV}$ by the transform type apparatus and the following result was obtained; the former stands comparison with the latter in showing contrast in bone. And the scattered radiation in the former is relatively little and can be eliminated by a small grid ratio.

\section{緒言}

従来胸部エックス線写真撮影においては, Contrast に富んでいる点, 散乱線の影響の少ない点などよりるつ ぱら低電圧による撮影法が推奖されてきたが最近に至り 肋骨及ご鎖骨に蔽われた部分，あるいは厚い筋肉叢と重 畳せる部分などの描写能を向上させるべく高電圧撮影法 が提唱されエックス線装置・散乱線除去装置などの進歩 に伴ってようやく実用の域に入ってきた。

われわれは変圧器式高電圧撮影装置を使用して高電圧 撮影を行うと同時に，近時多極エックス線管の発達に伴 い適当な波尾截断により蓄電器式エックス線装置の有效 管電压波形を央用的に矩形波となしうることに着目し， 短形波による胸部準高圧撮影の実験を行った。

われわれは三極回転陽極型エックス線管を装備した蓄 電器式装置（蓄電器容量 $2.0 \mu \mathrm{F}$ ） を用いて初期放電電圧 （允電電任） $90 \mathrm{kV}$, 截断電在 $87 \sim 89 \mathrm{kV}$ という僅少差截 断によって得た比較的硬エックス線で胸部撮影を行い, 同時に変圧器式単相全波整流装置による $60 \mathrm{kVp}, 90 \mathrm{kVp}$, $120 \mathrm{kVp}$ におけるそれぞれの平均エックス線質，骨㓌影 の消退度、散乱線効果などについて基礎的実験を行いあ
わせて臨床的意義についても検討したので報告する。

\section{実験に使用した装置並びに測定器}

1：エックス線装置 島津山城B型 最高電圧 $\quad 150 \mathrm{kVp}$ エックス線管 Circlex 2.0,0.3mm

基礎フィルター $1.5 \mathrm{mmAl}$

管電在直読・管電流自動選択装置 大阪レントゲン SIRIUS 920-T 型 最高電圧 $\quad 90 \mathrm{kV}$

エックス線管 Grid-controlledX-ray tube M-5066

基礎フィルター $1.5 \mathrm{mmAl}$

電生差による波尾截断方式装置

2 : 被写体 アルミ階段・カルシウム一階段・ パラフィンファントーム・人体

3 : 螢光量測定器 Photomultiplier CRC-931A 使 用による積算回路型

4 : 増感紙・フィルム 増感紙極光F.S, H.S, H.V 富士Xーレイフィルム

5 : 濃 度 計 東京光電製Multiplier photometer 
6:その の 他 リスホルム・ブレンデ

島津製・シェーナンデル・MS・竹 内製

\section{I. 増感紙に及ぼす平均エックス線質}

エックス線質の測定には植準電離槽型エックス線量計 によって半価層を测定するのが当を得た方法であるが， 蓄電器式装置の如く極く短時間に樭写の終了するような 場合電離槽の特性よりその測定が非常に困難になるのて われわれはアルミニウム・カイルを透過したエックス線 量を増感紙螢光体で受けこれを Photomultiplierによる 溃光量計にて测定し螢光量の減弱の度合により平均エッ クス線質を求めた。

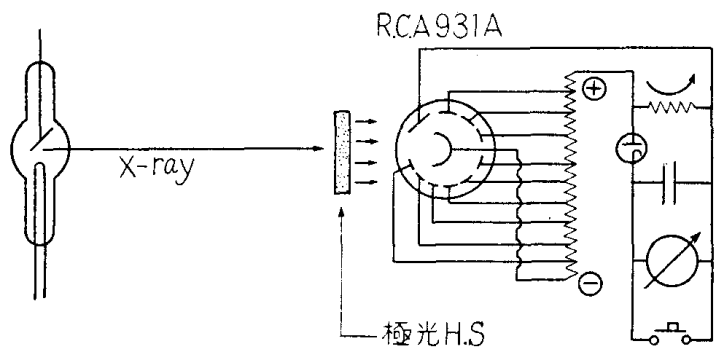

第1図螢光量测定器

実験に先立ち第 1 図に示すような積算回路型螢光量測 定器を作製した。螢光体として極光増感紙 H.S 在使用 しその螢光を CRC-931 A にて自己増倍せしめ光電流を 積算用蓄電器に充電させその允電電圧波高值を螢光量に 比例せしめた。

まず最初アルミ・カイルを挿入せず変圧器式単相全波 整流装置（以下単に変圧器式という）による $60 \mathrm{kVp}, 90$ $\mathrm{kVp}, 120 \mathrm{kVp}$ 及び波星截断方式蓄電器装置による充電 電圧 $90 \mathrm{kV}$ 截断電圧 $88 \mathrm{kV}$ (以下単に $90 \rightarrow 88 \mathrm{kV}$ と表わ す)，60 $\rightarrow 50 \mathrm{kV}$ のそれぞれのエックス線エネルギーを螢 光量計で同一ならしめる露出を選んだ。次にてれら 5 者 の撮影方式につき硋当露出で $0.5 \mathrm{~mm}$ より $15 \mathrm{~mm}$ までの アルミ板を増感紙前面に㧴入し營光量の減弱を表わした ものか第 2 図である。

この場合エックス線管に取付けた基礎フィルターはい

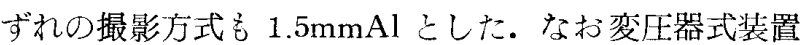
においては管瑇流值の大小により管電流波形に変化をき たし，ひいてはエックス線質に影響を及ばすことを考虑 乙管電流值は日常臨床的に使用する価を用い $60 \mathrm{kVp}$ の 場合は $300 \mathrm{~mA}, 90 \mathrm{kVp} \cdots \cdots 100 \mathrm{~mA}, 120 \mathrm{kVp} \cdots \cdot 50 \mathrm{~mA}$ 蓄電器式の場合 $60 \rightarrow 50 \mathrm{kV}, 90 \rightarrow 88 \mathrm{kV}$ こに $300 \mathrm{mAp}$ とした。

第 2 図に示す上打り容量 $2.0 \mu \mathrm{F}$ の蓄電器式撮影に求

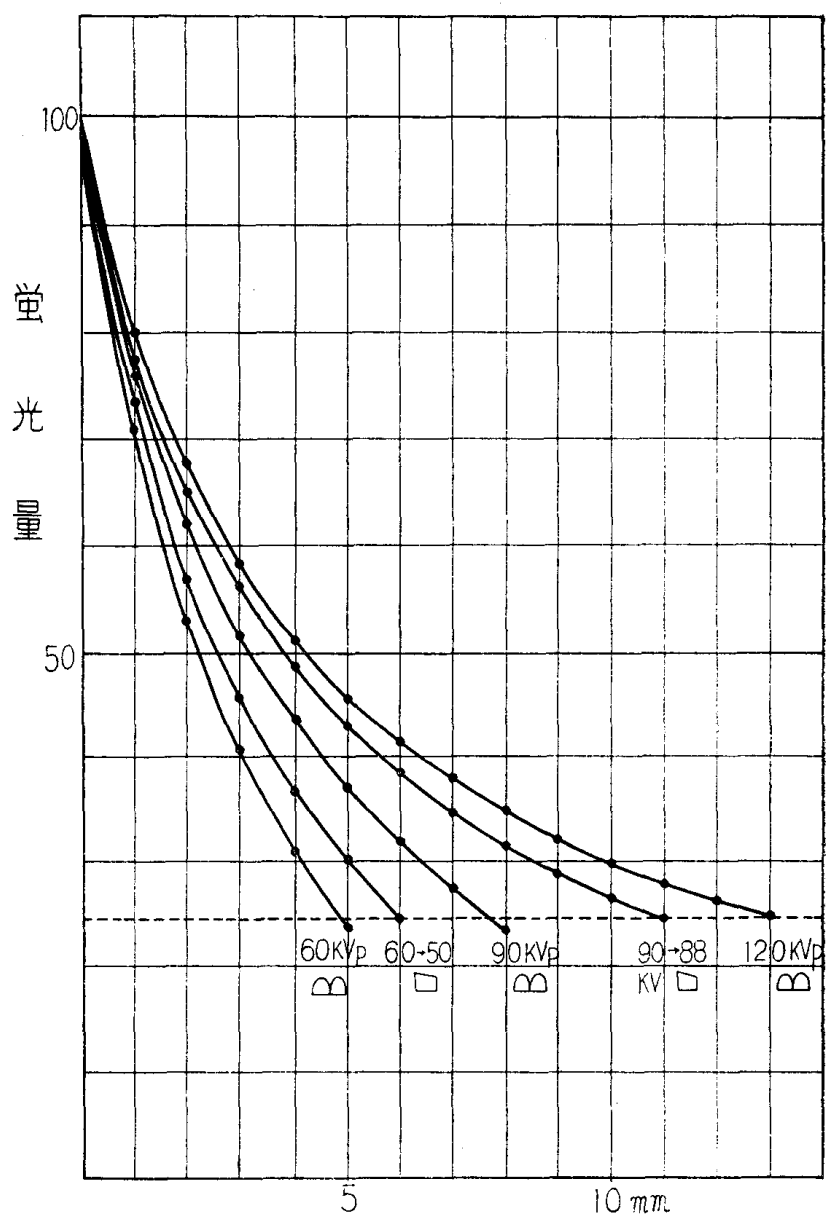

アルミニウム

第2図 平蚐エックス線䆵

いて $90 \rightarrow 88 \mathrm{kV}$ の場合その平均エックス線質は同じ管電 圧波高值の変圧器式 $90 \mathrm{kVp}$ に比較し相当硬くなり変圧 器 $120 \mathrm{kVp}$ のものにほぼ近似せることが判明した。 れにより Kulenkamp 並びに Duan-Hunt の実験式より 導き得たわれわれの予想が確認され増感紙に及ぼす平均 エックス線質は必ずしも管電圧波高值によらないことが 立証された。

なお，この螢光量測定法により半価首を求めることは 螢光物質の波長依存性よりみて妥些ではないが，同時に 行ったノン・スクリーンフィルム法こ大差は珰められな

第 1 表 螢光量測定法による半価層

変圧器式蓄電器式変压器式蓄電器式変圧器式

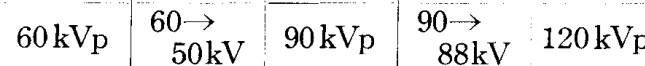

\begin{tabular}{|c|c|c|c|c|c|}
\hline $\begin{array}{l}\text { 第 I 半 } \\
\text { 俩 層 }\end{array}$ & $\begin{array}{r}2.2 \mathrm{~mm} \\
\mathrm{Al}\end{array}$ & $\begin{array}{r}2.5 \mathrm{~mm} \\
\mathrm{Al}\end{array}$ & $\begin{array}{r}3.0 \mathrm{~mm} \\
\mathrm{Al}\end{array}$ & $\begin{array}{r}3.8 \mathrm{~mm} \\
\mathrm{Al}\end{array}$ & $\begin{array}{r}4.0 \mathrm{~mm} \\
\mathrm{Al}\end{array}$ \\
\hline $\begin{array}{l}\text { 第 } \text { 半 } \\
\text { 俩 層 }\end{array}$ & $\begin{array}{r}2.6 \mathrm{~mm} \\
\mathrm{Al}\end{array}$ & $\begin{array}{r}3.5 \mathrm{~mm} \\
\mathrm{Al}\end{array}$ & $\begin{array}{r}4.8 \mathrm{~mm} \\
\mathrm{Al}\end{array}$ & $\begin{array}{r}7.2 \mathrm{~mm} \\
\mathrm{Al}\end{array}$ & $9.0 \mathrm{~mm}$ \\
\hline
\end{tabular}


いので実用的にての值をもって該当エックス線の半価膡

とし第 I表に掲載した.

\section{II. 骨陰影の消退度}

前項の実験より各撮影方式におけるそれぞれの平均工 ックス線質が判明し堛電器式 $90-88 \mathrm{kV}$ においては変圧 器式 $120 \mathrm{kVp}$ のもと実用的に等しいというととが言い 得るが果して骨陰影の消退度もこれに伴うものであろう からいう疑問を抱いたので検討を加えた．神田氏らの実 験によればアルミニウムと骨のエックス線減弱係数が近 似するためアルミニウムによる減弱の度合を以て骨㓌影 の消退度とみなし得ることが報告されているがわれわれ はこの実験の追試をも兼ねて次の実験を行った。

まず肋骨，鎖 骨とエックス線 吸収度の近似せ る物質を検討し た結果, $\mathrm{CaSO}_{4}$ • $1 / 2 \mathrm{H}_{2} \mathrm{O}$ 汇比較的 近似せる結果を 得たので第 3 図 のごとき階段を 作製し，それぞ れの撮影方式に

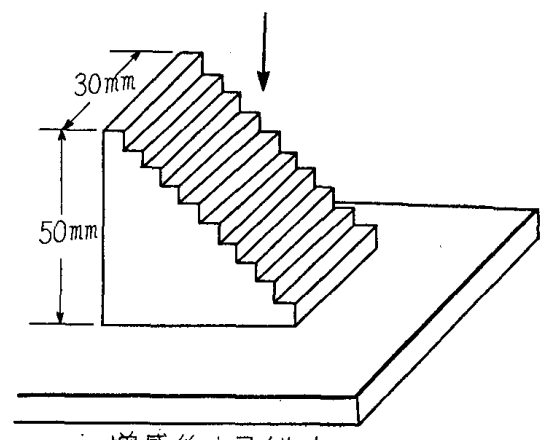

增感紙十フイルム

第3図骨の消退度実験

おいて素地黒化即ちファントームなしの部分が黒化度 2.0 になるような曝射を行った。この場合各撮影方式に おける管電流值は前項の実験と同一の条件にて行ない露 出の増減は F.P.Dのみによった，増感紙は極光 F.Sフィ ルムは富士 X-レイフィルムを用い，この時のフィルム r值は 3.0 であった。

その結果は第 4 図で示されるごとく骨によるエックス 線の減弱はアルミニウムによる減弱とほぼ等しく, 変压 器式 $120 \mathrm{kVp}$ のものと蓄電器式 $90 \rightarrow 88 \mathrm{kV}$ のもの濃度 差は肉腿的には判別できなかった。

これよりとの雨者における骨陰影の消退度は 実用的にみて同一であるといえるであろう.

\section{III. 散乱線の影響}

胸部撮影に際して管電圧を上昇させてゆくと 増感紙・フィルムに及ぼす散乱線の影響の増大 することは周知の事実であるが，それぞれの撮 影方式においてその効果がどのように影響する かについて定量的実験を行った。

われわれの計画した実験方法としてはノン・

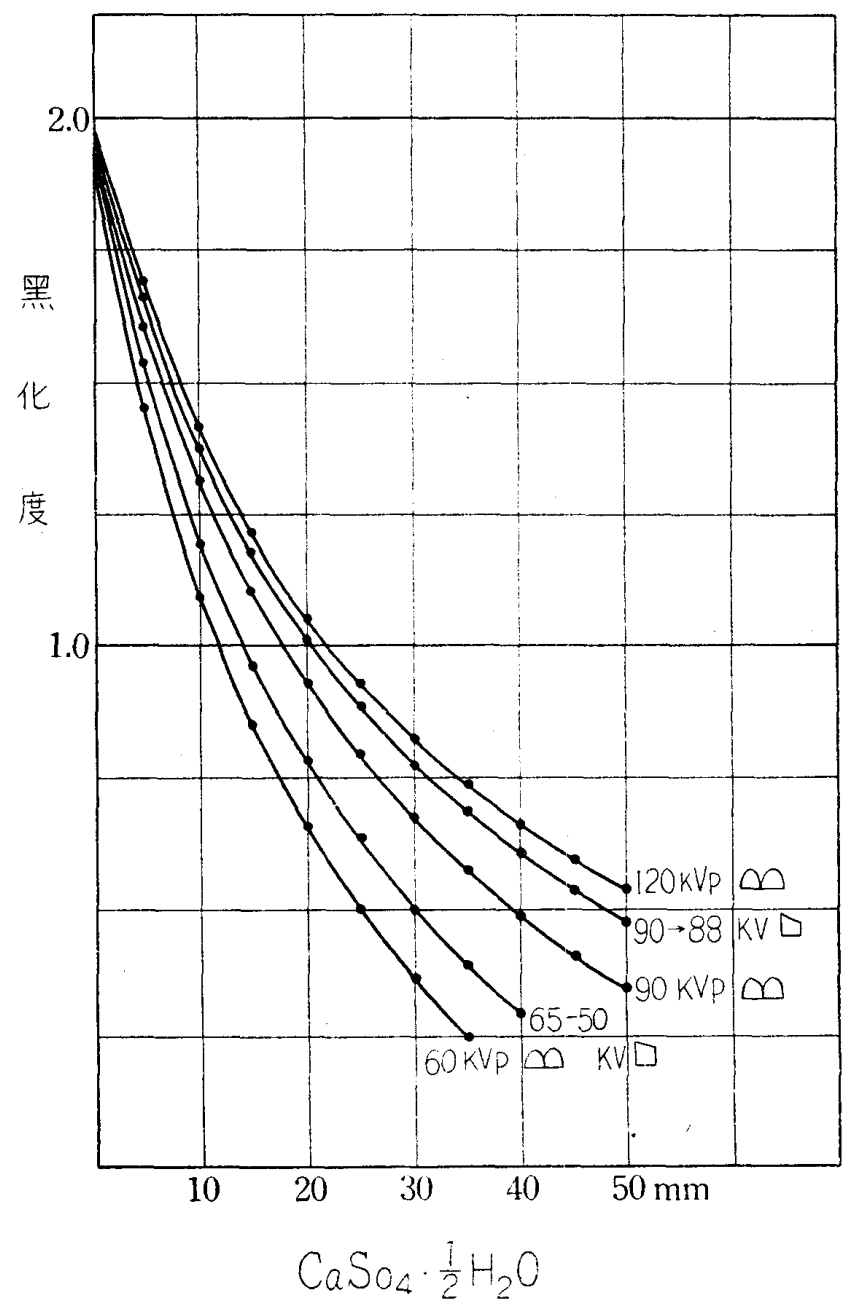

第 4 図 骨陰影の消退度

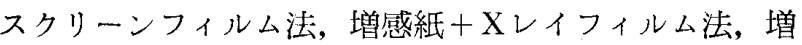
感紙螢光量法の 3 者であるが種々検傠の結果第 1 者につ いては直接線一散乱線の波長分布の広汎なため, 実際に 使用する増感紙との波長依存性の差が大となるため, 第 2 者については写真測光学上無視でき得ない程度の相関 不軌の問題（いわゆる Schwarz-schild のP指数）が関 与してくるため螢光量測定法に頼るよりほかはなかった。

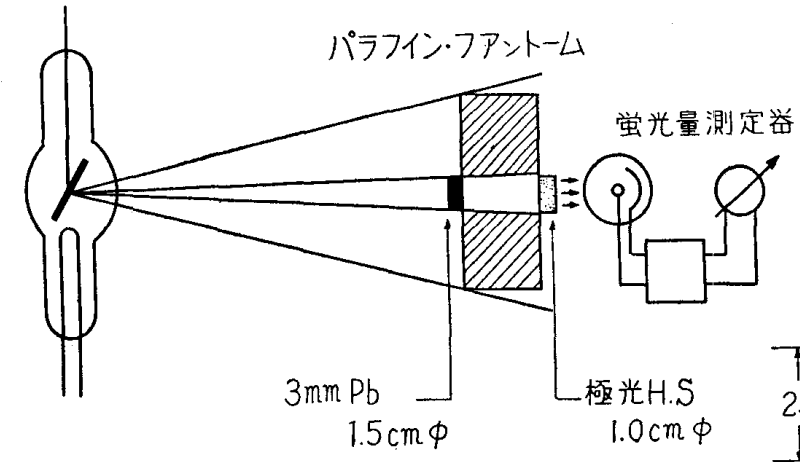

第 5 図散乱線含有率測定

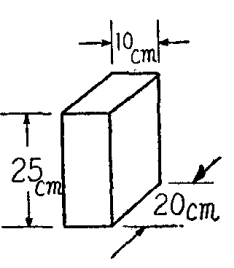


実験に先立ち写真効果，散乱効果とも人体に類似せる 被写体として予備実験の結果, 横 $20 \mathrm{~cm}$, 縦 $25 \mathrm{~cm}$, 厚さ $10 \mathrm{~cm}$ のパラフィンファントームを選んだ。奏験方法は 第 5 図に示すごとくエックス線管，ファントーム，增感 紙（極光 H.S $1.0 \mathrm{~cm} \phi ）$ を配置し，変圧器式 $60 \mathrm{kVp}, 90$ $\mathrm{kVp}, 120 \mathrm{kVp}$, 蓄電器式 $90 \rightarrow 88 \mathrm{kV}$ でそれぞれ曝射を 行ないその時の増感紙の螢光量を前記の螢光量計で測定 した．勿論この值はファントームを透過した直接線 $I_{d}$ とファントームより発生した散乱線 $I_{s}$ の和で $I_{d+s}$ で表 わした。

次にファントームの前面中央に直径 $1.5 \mathrm{~cm}$ の鉛板 (3 $\mathrm{mm}$ 厚）を密着し，先の実験と同じく焦点——鉛板中心 を結ぶ線上に増感紙を置きそれぞれ先の実験と同一条件 で曝射を行ない螢光量計で測定した。この場合直接線は 前面の鉛に遮ざられ増感紙に到達しないので，乙の価は ファントームよりの散乱線 $I_{s}$ のとみなすととができ る。従って散乱線含有率は

$$
\frac{I_{s}}{I_{d+s}} \times 100 \%
$$

で表わされる。

以上の実験より増感紙に及ぼす散乱線の影響は第 6 図 に示すとおり変庄器式においては管電圧の上昇に伴って 増加し， $120 \mathrm{kVp}$ においては実に $63 \%$ にも達しているに

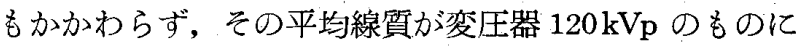
近似している蓄電器式 $90 \rightarrow 88 \mathrm{kV}$ においては $50 \%$ しか含 有されないというととは特筆に值する，換言すればほぼ 同様な線賈を有しながら蓄電器式 $90 \rightarrow 88 \mathrm{kV}$ の方が変圧 器式 $120 \mathrm{kVp}$ より約 2 割も散乱線の発生率が少いことに

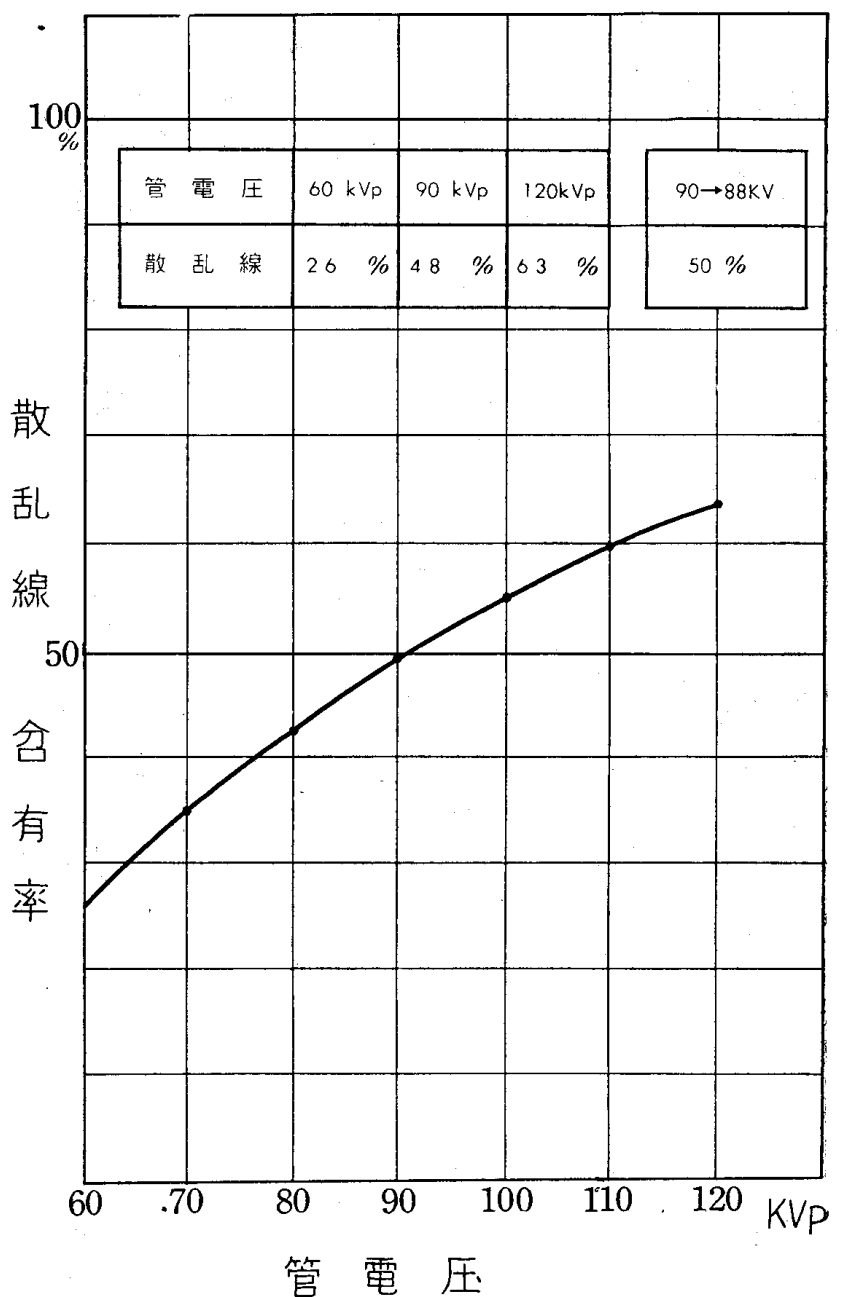

第 6 図散乱線含有率

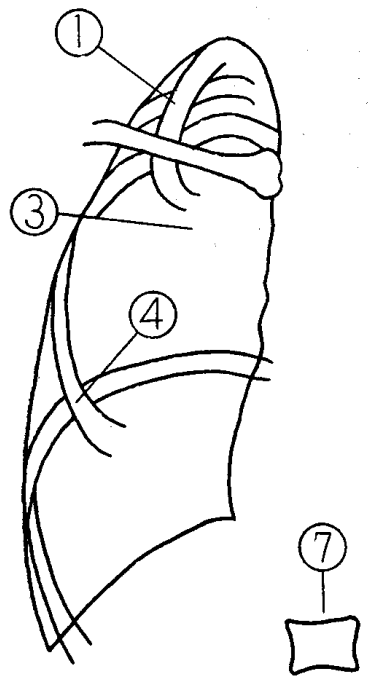

胸咟 $18 \mathrm{~cm}$ 우
(2)

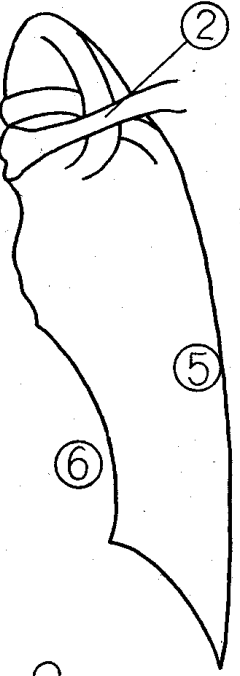

(5)

\begin{tabular}{|c|c|c|c|c|c|}
\hline & 部位 & $\begin{array}{c}60 k v_{p} \\
M \\
\end{array}$ & $\begin{array}{c}90 \mathrm{k} v_{p} \\
M\end{array}$ & $\begin{array}{l}90 \rightarrow \\
88 \mathrm{KV} \\
\end{array}$ & $\begin{array}{c}120 \mathrm{kvp} p \\
M \\
\end{array}$ \\
\hline 1 & III - 1 肋骨交少部 & 0.70 & 0.74 & 0.86 & 0.84 \\
\hline 2 & N $\cdot 1$ 助骨十鎖骨 & 0.43 & 0.52 & 0.72 & 0.70 \\
\hline 3 & NV・V助間肺野 & 1.30 & 1.28 & 1.25 & 1.26 \\
\hline 4 & VII ・4助骨交少部 & 0.58 & 0.68 & $\mid 0.80$ & 0.82 \\
\hline 5 & 側 “胸部 & 0.56 & 0.76 & 0.86 & 0.86 \\
\hline 6 & 心贜陰影 部 & 0.32 & 0.40 & 0.50 & 0.53 \\
\hline 7 & カブリ值（XI胸椎） & 0.20 & 0.20 & 0.23 & 0.22 \\
\hline
\end{tabular}

ローマ数字は後部助骨・アラビア数字は前部助骨

第 7 図 臨床写真における各部位の濃度 


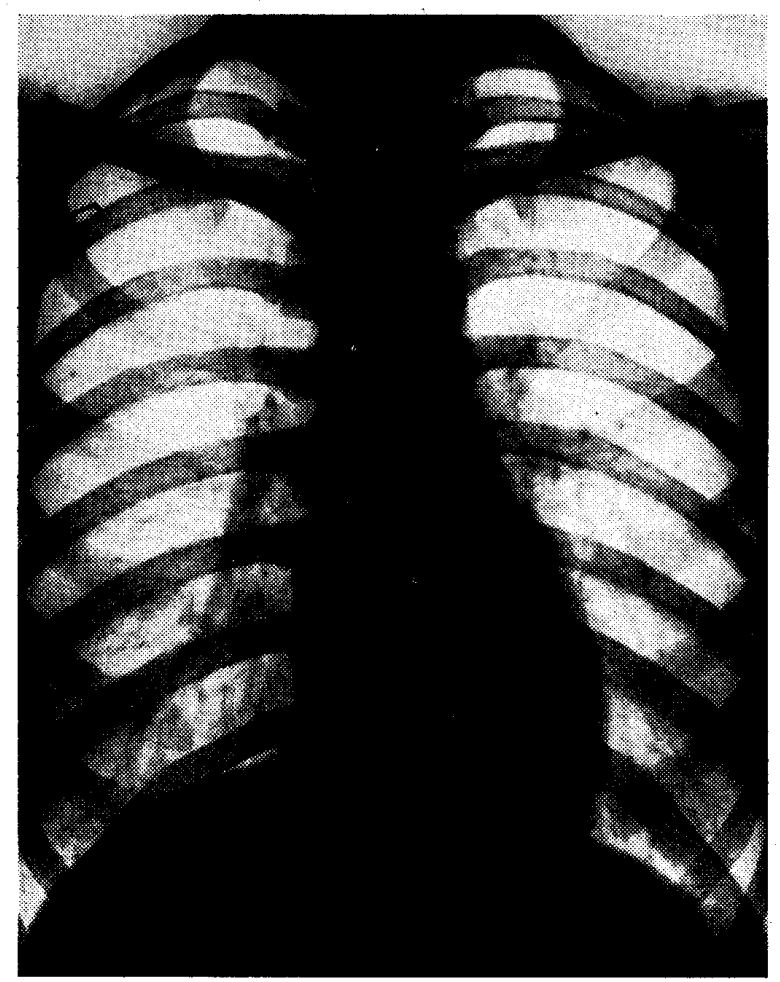

第 8 図 変圧器式 $60 \mathrm{kVp}$ リスなし

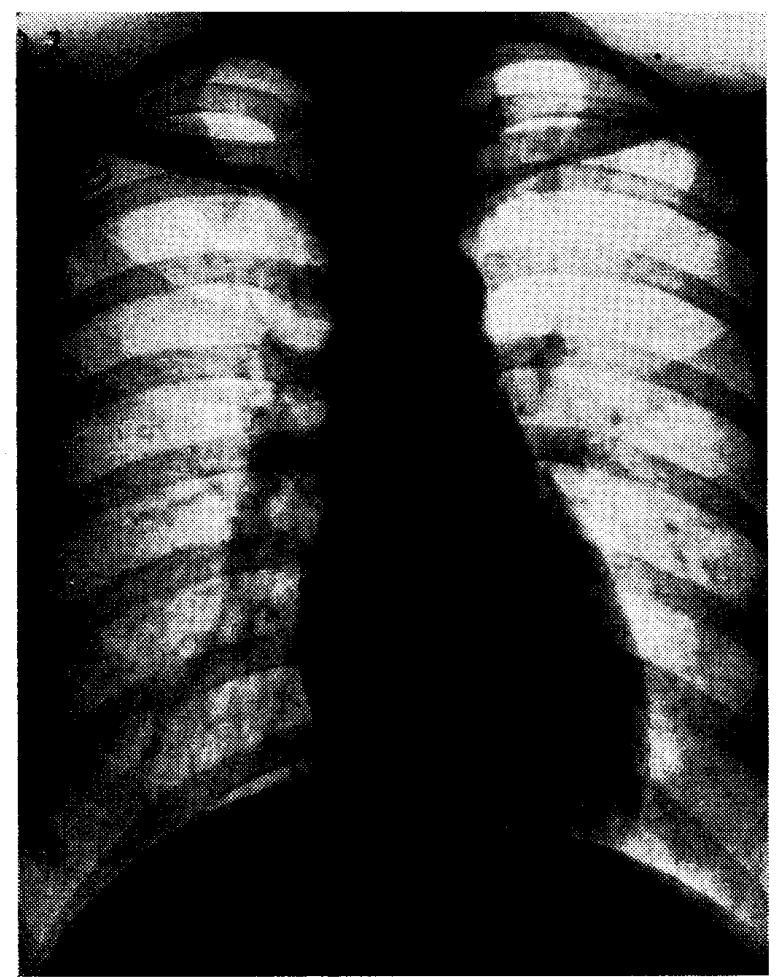

第10図 蓄電器式 $90 \rightarrow 88 \mathrm{kVp}$ リス $6: 1$ シングル

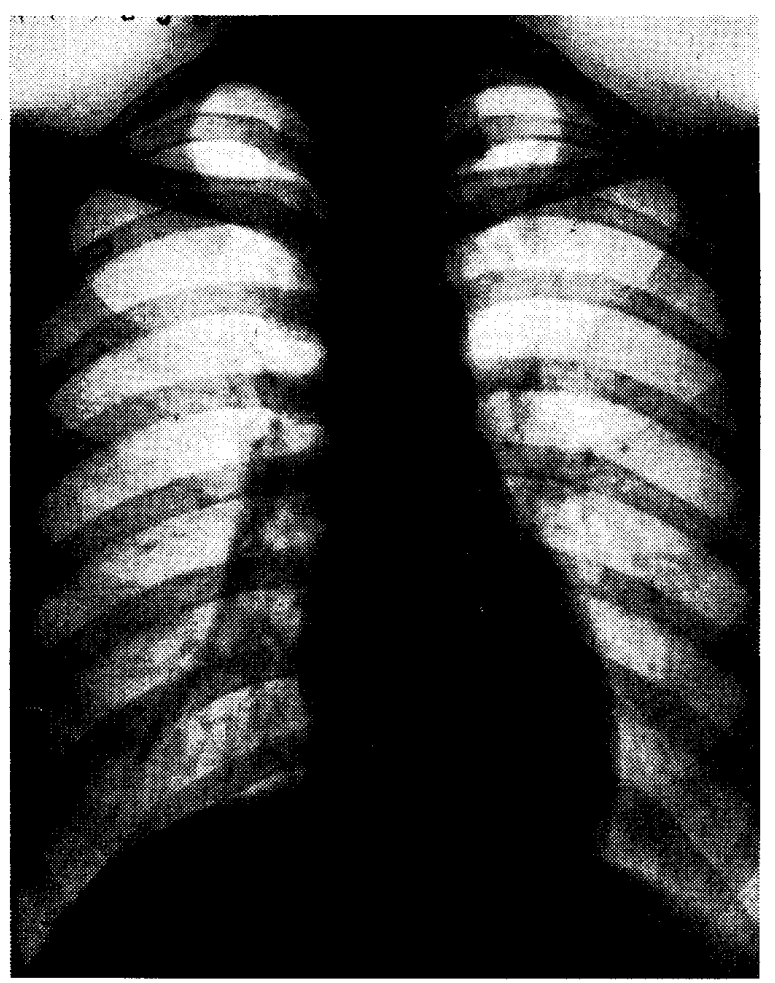

第 9 図 変圧器式 $90 \mathrm{kVp}$ リス $6: 1$ シングル

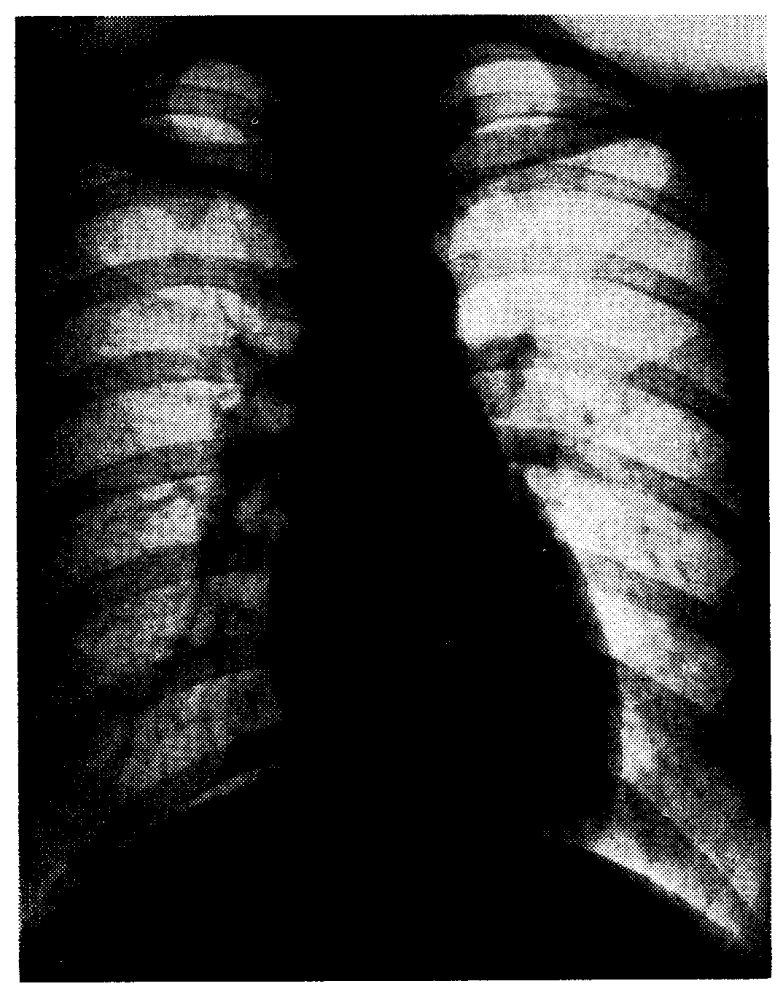

第11図 変圧器式 $120 \mathrm{kVp}$ リス 10:1 シングル 
なるこのことは蓄電器式 $90 \rightarrow 88 \mathrm{kV}$ の場合，その管電 圧は一応矩形波とみなし得るので定電圧波形として, Kulenkamp 並びに Duane-Hunt の実験式に代入するる その最短波長 $\lambda_{0}$ と最強波長 $\lambda_{\text {max }}$ の間には $\lambda_{\max }=1.3 \sim$ 1.5 $\lambda_{0}$ なる関係が成立するが，変圧器式の管電圧波形は 正弦波を描くので発生するエックス線の波長分布は，そ の瞬時值のスペクトル分布の積分值で表わされるため $\lambda_{0}$ と $\lambda_{\max }$ との間には前式が適用されず，その定数值が 大となるため定電圧波形に較べ同じ最強波長（平均エッ クス線質）にもかかわらず最短波長が短くなるため，乙 れか潵乱線発生率侸影響するものと考えられる。

次にこれらの散乱線をいずれる25一 $30 \%$ に抑えるため 各種の格子比のリスホルムブレンデを使用し同様の実験 を行った結果, 変圧器式 $90 \mathrm{kVp}$, 蓄電器式 $90 \rightarrow 88 \mathrm{kV}$ の ものでは格子比 $6: 1$, 変圧器式 $120 \mathrm{kVp}$ においては $10: 1$ 程度のもので除去可能なととが判明した。

\section{IV. 臨 床 的 成 績}

以上の基礎的実験より蓄電器 $90 \rightarrow 88 \mathrm{kV}$ の撮影方式は 変圧器式 $120 \mathrm{kVp}$ と比較し平均エックス線質, 骨陰影の 消退度はほぼ同等で，散乱線含有率においては有利なて とが確㸾されたので，次のでとき撮影条件で同一被写体 (23歳早胸厚 $18 \mathrm{~cm})$ を撮影した。

変任器式 $\quad 60 \mathrm{kVp} \quad 300 \mathrm{~mA} \quad 0.08 \mathrm{sec}$ リスホルム無 変圧器式 $\quad 90 \mathrm{kVp} \quad 100 \mathrm{~mA} \quad 0.10 \mathrm{sec} \quad 6: 115$ 本 $/ \mathrm{cm}$ 蓄電器式 $\quad 90 \rightarrow 88 \mathrm{kV} \quad 300 \mathrm{mAp}(0.012 \mathrm{sec}) 6: 115$ 本 $/ \mathrm{cm}$ 変圧器式 $\quad 120 \mathrm{kVp} \quad 50 \mathrm{~mA} \quad 0.08 \mathrm{sec} \quad 10: 120$ 本 $/ \mathrm{cm}$

第 7 図はこれらのエックス線写真フィルムの各部位の 濃度を濃度計で測定したものである。これょり明らかな とおり各撮影方式において $\mathrm{N}, \mathrm{V}$ 肋間肺野濃度を一定に

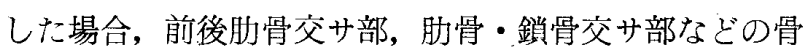
陰影の消退度は変圧器式 $120 \mathrm{kVp}$ のもと蓄電器式 $90 \rightarrow$ $88 \mathrm{kVp}$ は実用的にみて全く同様であった。なお同被写
体における左肺尖部（2）－1肋骨十鎖骨部）の乾酪性 病紧の現出能にも差異を認めなかった。

そのほか胸厚 $17 \mathrm{~cm}$ より $23 \mathrm{~cm}$ までの被写体数例につ いて充電電圧 $90 \mathrm{kV}$ ，截断電圧 $86 \sim 89 \mathrm{kV}$ の間において 同様の実験を行なった結果，いずれも変圧器式 $120 \mathrm{kVp}$ 撮影と同等の効果のあることが立証された。

なお，今回の実験は波尾截断方式を装置の関係上電圧 差截断により行なったが，臨床的に使用する場合にはを の截断範囲があまりにも狭小なので撮影条件の決定，操 作か涃難なためエックス線管通電量 (いわゆる $\mathrm{mAs}$ 法) 截断方式により行うのが適切と考えられる。

\section{結論}

以上の基礎実験並びに臨床実験より次の事項を結論す る.

$1:$ 増感紙に及ぼす平均エックス線買は蓄電器式 $90 \rightarrow 88$ $\mathrm{kV}$ の場合変圧器 $120 \mathrm{kVp}$ のそれに近似し，骨除影の消 退度においても同様の結果を得た。

$2:$ 散乱線含有率は蓄電器式 $90 \rightarrow 88 \mathrm{kV}$ の場合同等の平 均線質を持つ変圧器式 $120 \mathrm{kVp}$ 亿比較し相当少なく, 変圧器式 $90 \mathrm{kVp}$ のものとほぼ同量である. 従って格子 此の小さなブレンデで除去が可能である.

3 : 臨床写真においても蓄電器式僅少差截断準高圧撮影 （充電電圧 $90 \mathrm{kV}$ 截断電圧 $86 \sim 89 \mathrm{kV}$ ）によるものは変圧 器式 $120 \mathrm{kVp}$ 程度のいわ功る高圧撮影」に比して遜色 がない。

$4:$ 以上の結果より，管電圧波高值を以てのみその効果 を論ずることは罗当でない．

〔註】以上の結論恃蓄電器容量 $2.0 \mu \mathrm{F}$ に打ける実駼結 果に基づいたものである。

報告を終るに際し本実験亿忽切なる御指導と御助言を いただいた当学黒沢洋教授並びに研友全会員諸氏に深謝 の意を表する次第である。 